\title{
Er islamismen populistisk, eller er populismen i Mellemøsten blevet islamistisk?
}

Af Jørgen Baek Simonsen, lektor, dr.phil., Institut for Tvarkulturelle og Regionale Studier, Københavns Universitet

Artiklen diskuterer og sammenligner de forskellige former for populisme, der har proget den politiske udvikling i Mellemøsten siden begyndelsen af det 20. århundrede. Det konkluderes, at den ikke-militante islamisme har spillet en afgørende rolle og evnet at sikre sig bred folkelig opbakning. Det var også tilfaldet $i$ Iran, hvor kredsen omkring Khomeini målrettet italesatte opgøret med shahen i en shiitisk islamisme.

Hvad er populisme, og hvad vil artiklen?

Populisme som begreb og fænomen har præget den europæiske debat gennem de seneste årtier. I den akademiske verden har der været en omfattende debat, dels om hvorledes begrebet skal forstås, og dels om det overhovedet kan bruges analytisk med henvisning til, at begrebet er flydende og uden et klart defineret indhold. I The Oxford Handbook of Political Ideologies fremhæver Mudde og Kaltwasser (2013), at populisme sjældent benyttes som en karakteristik af personer eller organisationer selv, men derimod er en betegnelse, der bruges om andre personer og grupperinger og ofte med en negativ undertone. På linje med den tyske politolog og idéhistoriker Jan-Werner Müller fastholder de imidlertid, at begrebet har sin selvfølgelige og anvendelige plads i den politiske analyse, fordi det er funderet på en række eksplicitte karakteristika, uanset hvilken ideologisk tendens det konkrete eksempel på populisme repræsenterer. De definerer derfor populisme som "a thin-centred ideology that considers society to be ultimately separated into two homogeneous and antagonistic camps, 'the pure people' versus "the corrupt elite"” (Mudde og Kaltwasser 2013, 498). Jan-Werner Müller fremhæver i forlængelse heraf, at populisme er udpræget antipluralistisk og tillige stærkt ekskluderende (Müller 2016 s. 134). Både Mudde og Kaltwasser samt Müller understreger, at den populisme, der gennem de seneste årtier har været så dominerende, er tæt forbundet med den forandring, Europa har gennemlevet de seneste årtier, hvor et voksende antal personer fra alle dele af den tredje verden har bosat sig og af mange opfattes som en trussel mod det kendte og det nationale. 
Populisme er således et fænomen, der hører det moderne samfund til og trives godt både med og uden en institutionaliseret og demokratisk sanktioneret politisk medbestemmelse og er derfor ikke er et fænomen alene knyttet til et pluralistisk demokratisk system. Det har vi kunnet iagttage i Mellemøsten, hvor befolkningernes aktive deltagelse i det politiske liv i de fleste tilfælde og gennem lange perioder har været stærkt begrænset eller helt fraværende (Angrist 2013).

Målet med denne artikel er at påvise, at populisme har spillet en central rolle i det politiske liv i det moderne Mellemøsten. Ligesom resten af den tredje verden blev det meste af Mellemøsten underlagt europæiske kolonimagter og måtte derfor gennem en politisk kamp for at sikre sig politisk uafhængighed og status som selvstændige, suveræne nationalstater (Rogan 2009). I kampen for selvstændighed handlede de forskellige nationale grupperinger på vegne af folket, og de forskellige bevægelsers taler og deklarationer var formuleret $i$ et sprog, der altid havde folket og dets fremtid som omdrejningspunkt. De nationale bevægelser var ofte xenofobiske og fastholdt, at de europæiske kolonimagter måtte ud af landet og overlade det til folket, der så kunne indrette sig som det fandt bedst. De nationale bevægelser i Mellemøsten formulerede sig alle i et populistisk sprog, hvor fremtiden fri af kolonimagterne ville blive indledningen til en gylden fremtid. Med empirisk udgangspunkt i Egypten og Iran vil artiklen illustrere, hvorledes islamisme defineret som en politisk, ideologisk brug af islam i forskellige formuleringer har italesat sig selv og udfordret andre populistiske ideologier i regionen.

\section{Egypten og Det Muslimske Broderskab}

Islam som reference blev kun sporadisk benyttet i den nationale kamp for selvstændighed, og ingen steder var det på tale, at den nationale kamp skulle sikre etableringen af et politisk system baseret på islam. Det blev kun tilfældet i Saudi Arabien, hvor den i 1932 etablerede saudiske stat blev funderet på et erklæret islamisk grundlag (Ayoob 2009). I alle andre tilfælde var målet etableringen af en nationalstat, hvor folket skulle have medbestemmelse og aktivt deltage i det politiske liv. Men den uafhængighed, Egypten sikrede sig i 1922/1923, blev tydeligvis ikke opfattet som tilstrækkelig, og mellemkrigstiden blev præget af en national kamp mod den fortsatte engelske tilstedeværelse i landet (Vatikiotis 1980). I 1928 tog en nyuddannet lærer ved navn Hassan al-Banna (19091949) initiativ til etablering af Det Muslimske Broderskab. Bevægelsen skulle gennemføre en omfattende og bredt anlagt oplysningskampagne og være med til at sikre, at den egyptiske befolkning - folket - fik den nødvendige viden om islams sande værdier. Den nyuddannede lærer erfarede kort tid efter sin ankomst til Ismailiyya ved Suez-kanalen, at mange fattige egyptere hverken havde den ønskede eller den fornødne viden om islam, og at de derfor var et let bytte for den sekulære tilgang til livet, som blev faldbudt af mange (Mitchell 1969).

Det skulle der sættes ind over for, og derfor skulle Broderskabet lancere en civil aktivisme, der konkret og praktisk kunne vise, at islam var andet og mere end tro i or- 
dets snævre betydning. Tro var også at handle, og kun ved en sådan aktivistisk forståelse af islam ville det blive muligt at dokumentere, at islam var en reference af betydning for livet $i$ alle dets mangfoldige facetter (al-Banna 1975). Det skal fremhæves, at alBanna i flere af sine skrifter argumenterer for, at en sådan strategi ville bidrage til, at de sande og autentiske islamiske værdier, der tidligere i historien havde skabt den klassiske islamiske civilisation, igen kunne finde indpas og bidrage til en nødvendig kulturel renselse af det egyptiske folk af den forurening, det var blevet påført under den engelske tilstedeværelse. I flere af sine skrifter henvender han sig direkte til de mange egyptere, der ikke længere aktivt praktiserer islam i overensstemmelse med den forståelse han og Broderskabet gjorde gældende. Deres daglige liv og virke var i voksende omfang blevet præget af værdier og normer introduceret af den administration, England havde opbygget efter invasionen i 1882. De var derfor på vej væk fra gruppen af sande og autentiske egyptiske muslimer, og den bevægelse skulle bremses (se skriftet Mod lyset i al-Banna 1975).

At denne udprægede populistiske lancering af islam som et værn i forsvaret af det, Broderskabet forstår som sande muslimske værdier, havde en stærk folkelig gennemslagskraft kan aflæses af den næsten eksplosive vækst, bevægelsen oplevede gennem 1930 'erne og $1940^{\prime}$ erne. Broderskabets centrum blev snart flyttet fra Ismailiyya til hovedstaden Kairo, og herfra gennemførtes en målrettet organisering af bevægelsen i alle egne af Egypten og siden også i andre arabiske lande i regionen (Mitchell 1969; Lia 2006). Al-Banna fastholdt, at den forståelse af islam, han udviklede, ikke var politisk i ordets sædvanlige betydning, og af samme grund udviklede bevægelsen sig hverken under hans eller hans efterfølgere til et traditionelt politisk parti. Men uanset dette var Broderskabet i kraft af sin målrettede aktivisme med til på afgørende vis at påvirke den offentlige debat.

Broderskabet var centralistisk og hierarkisk organiseret. Al magt blev samlet hos lederen og den selvsupplerende kreds omkring ham og sigtede på ingen måde på at inddrage de menige medlemmers aktive deltagelse i formuleringen af bevægelsens program. Broderskabets mange aktive medlemmer virkede i deres respektive sociale sammenhænge som loyale repræsentanter, der gennem deres aktivistiske engagement skulle invitere andre til at tilslutte sig bevægelsen. Al-Banna taler i sine skrifter mere om umma-en - de rettroende muslimers samfund - end om folket, og af samme grund havde hverken han eller bevægelsen den kristne koptiske minoritet som mål for bevægelsens virke, selvom de oplysningskampagner, den gennemførte, forsøgte at konvertere kristne koptere til islam og dermed træde ind i umma-en. Kopterne udgjorde i denne periode omkring $15 \%$ af den egyptiske befolkning, medens den nu menes at udgøre $8-10 \%$.

Nationalisme og islamisme i Egypten

Populisme som politisk strategi kan udmærket praktiseres i et politisk system, der er baseret på pluralistisk folkelig deltagelse gennem afholdelse af tilbagevendende valg, og 
sådan var det politiske system i Egypten formelt organiseret $\mathrm{i}$ tiden mellem grundlovens lancering i 1923 og det militære kup i 1952. Perioden var domineret af modsætningsforholdet mellem skiftende nationalistiske regeringer på den ene side og kongen, der ifølge grundlovens bestemmelser havde meget store udøvende beføjelser, på den anden side. Kongen var derfor igen og igen i stand til at begrænse den politiske indflydelse, det nationalistiske Wafd-parti fik uanset det forhold, at partiet sejrede ved det ene valg efter det andet (Terry 1982). Broderskabet på sin side afstod fra at organisere sig som et politisk parti og fokuserede først og fremmest på at re-islamisere befolkningen og ved enhver mulig lejlighed at slå til lyd for, at islam var det sande egyptiske folks fundament. Derfor skal vi helt frem til slutningen af 1900-tallet før bevægelsen for alvor begyndte at overveje at etablere sig som et politisk parti, selvom det i forbifarten skal nævnes, at et voksende antal individuelle medlemmer fra midten af $1980^{\prime}$ 'erne deltog i valg til det egyptiske parlament som kandidater for flere forskellige politiske partier (Rutherford 2013).

Broderskabet blev efter et militært kup, gennemført af en gruppe unge officerer i juli 1952, politisk udmanøvreret. På vegne af det egyptiske folk lovede de nye nationalistiske militære magthavere anført af Nasser en ny og strålende fremtid for det egyptiske folk, dersom det ville støtte det program, de nye magthavere præsenterede. Det var baseret på opbygningen af et stærkt militær, der kunne forsvare nationen mod ydre fjender, og en sådan var blevet skabt, da den jødiske stat Israel så dagens lys i maj 1948. Sammen med andre arabiske stater havde Egypten erklæret den nye stat krig, men lidt et forsmædeligt nederlag (Rogan 2009).

Derfor skulle der gøres op med det politiske, pluralistiske system, der var blevet skabt ved overgangen til den delvise selvstændighed i 1922-23. Landet havde i de nye militære magthaveres udlægning i virkeligheden været styret af udenlandske interesser og havde derfor ikke tjent folkets interesser - et klassisk populistisk argument, der ofte blev benyttet (se f.eks. Nasser 1952). Derfor forbød det nye regime alle politiske partier og etablerede i stedet et enhedsparti, der skulle sikre magthaverne en institutionel ramme gennem hvilket regimet kunne mobilisere befolkningens støtte til dets kamp for at gøre op med den koloniale fortid. Det løfte blev aldrig for alvor indfriet, og de tre forskellige enhedspartier, der blev skabt i Egypten gennem 1950'erne og 1960'erne, blev aldrig organiseret på et generelt princip om direkte indflydelse fra den brede befolknings side (Angrist 2013). De forskellige enhedspartiers propaganda var præget af en populisme, der gennem årene blev formuleret med lidt skiftende indhold, og det var først fra 1962 og med etableringen af Den Arabiske Socialistiske Union, at regimets populistiske propaganda blev panarabisk og socialistisk (Waterbury 1983). Men det skal fremhæves, at både Broderskabet og enhedspartierne ideologisk fastholdt nødvendigheden af, at landet kom fri af den økonomiske, politiske og kulturelle afhængighed, de vestlige kolonimagter havde påført ikke bare Egypten men også andre arabiske stater. 
Radikal militant islamisme

Den centrale position, Broderskabet sikrede sig efter sin etablering, var et resultat af den dygtige og målrettede italesættelse, der prægede bevægelsens publikationer, hvad enten det var al-Bannas egne skrifter eller dens officielle tidsskrift, men den store gennemslagskraft, bevægelsen havde i den offentlige debat, blev som nævnt ikke omsat i egentlige målrettede og traditionelle politiske initiativer. I 1954 blev Nasser mål for et mislykket politisk attentat, hvilket resulterede i, at Broderskabet blev erklæret forbudt og efterfølgende gjort til genstand for en målrettet og særdeles hårdhændet undertrykkelse. Blandt de mange medlemmer, der blev fængslet, var Sayyid Qutb (1906-1966), der fra begyndelsen af 1950'erne var blevet en af Broderskabets vigtigste penneførere (Bergesen 2008). Han blev i 1966 anklaget for meddelagtighed i planlægningen af et kup rettet mod Nassers regime, og under retssagen blev hans skrift Ma'âlim fí-l-tarîq (Milestones) brugt af anklagemyndigheden som dokumentation for hans bidrag til planlægningen af det postulerede kup. Det blev under retssagen ikke faktuelt dokumenteret, hvilket dog ikke forhindrede myndighederne i at henrette ham (Moussalli 1992).

De tanker og ideer, Qutb formulerede i sine skrifter forfattet under sit fængselsophold og smuglet ud for senere udgivelse, fik efterfølgende stor betydning for den militante radikalisering, flere islamistiske grupper gennem de følgende årtier kom til at repræsentere i Egypten (Toth 2013). Det Muslimske Broderskabs ledelse, anført af Hassan al-Hudaybi (1891-1973) og udpeget som ny leder af Broderskabet i 1951, forsøgte efter bedste evne at distancere sig fra de radikale synspunkter, Qutb formulerede i årene før sin henrettelse. I overensstemmelse med al-Bannas bærende ide om, at bevægelsen var en aktivistisk folkelig bevægelse, fastholdt den nye leder, at den skulle bibeholde sit fokus på at islamisere det egyptiske samfund gennem da'wa (invitation /mission/oplysning), før det ville blive muligt at skabe et nyt stærkt islamisk samfund og en islamisk stat (Zollner 2012). Qutb på sin side gjorde gældende, at selvom det egyptiske regime hævdede at være muslimsk, så var det det i virkeligheden ikke, fordi hverken staten eller lovgivningen var funderet på sande islamiske principper. Det egyptiske regime var udtryk for jahiliya - uvidenhed - og således illegitimt. Derfor skulle det fjernes, og Qutb udviklede i den forbindelse en ide om opbygning af en særlig gruppe af elitemedlemmer ( $\operatorname{tali}^{\prime} a$ ), der kunne føre an i en væbnet militant kamp mod det illegitime politiske system, der styrede Egypten (Moussalli 1992; Toth 2013). Medens den islamisme, al-Banna havde argumenteret for, havde taget udgangspunkt $i$ et behov for folkelig (ud)dannelse, (gen)opdragelse og retledning for ad den vej at forme muslimer, der fulgte og praktiserede den sande forståelse af islam, blev Qutbs ideer om en væbnet militant kamp som redskab til at skabe en sand islamisk stat fra begyndelsen af 1970 'erne grundlaget for militante islamisters kamp mod først Sadat og siden Mubarak (Kepel 2003).

Da Nasser døde i 1970 blev Anwar al-Sadat ny præsident, men ingen troede for alvor på, at han ville kunne opretholde magten (Finklestone 1998). Den antagelse skulle snart vise sig at være forkert, og gennem de følgende år indledte han forhandlinger og 
siden aftaler med fængslede ledere af Det Muslimske Broderskab, der takkede ja til et samarbejde med den nye præsident. Broderskabet fik som følge heraf mulighed for igen aktivt at virke mod utvetydigt at tilkendegive, at bevægelsen ikke ville deltage i forsøg på at vælte det eksisterende politiske system (Hirst 1981). Gennem 1970'erne lancerede Sadats regime i alle statslige medier - og dengang var der ikke andre - et billede af ham som ra'îs al-mu'minîn - de troendes proesident, ligesom det igen og igen blev understreget, at det politiske system, han stod i spidsen for, virkede i overensstemmelse med sande islamiske principper og traditioner. Tendensen til at italesætte regimet med brug af islamisk retorik viser Sadat-regimes klare forståelse af, at Broderskabet også under den hårde undertrykkelse, bevægelsen blev udsat for under Nasser-regimet, havde været i stand til at fastholde sin betydning og fortsat omtale sig selv i et sprog, der fandt genklang i den brede befolkning.

Den kamp, militante islamistiske grupper førte mod det egyptiske regime, skulle komme til at strække sig over flere årtier, men førte ikke til det ønskede resultat. Og medens Broderskabet fortsat arbejdede på at sikre sig bred folkelig opbakning, baserede militante grupperinger som Jama'at al-Muslimîn og Jama'at al-Jihâd deres indsats på skabelsen af en elitær fortrop, der kunne føre an i kampen mod regimet. Den militante gruppering Jama'at al-Islamiyya forsøgte som Broderskabet i opråb og gennem udgivelse af mindre skrifter og pamfletter at skaffe sig en bred folkelig opbakning men uden held. De militante gruppers italesættelse af militant islamisme fandt ikke genklang hos ret mange, men såvel de militante radikale grupperinger som Det Muslimske Broderskab var på hver sin måde med til at presse regimet til officielt at bekende sig til islam. Det kom formelt til udtryk ved ændringen af den egyptiske grundlov i 1980, hvor islamisk lov defineres som hovedkilden for landets lovgivning. I grundloven af 1973 var islamisk lov omtalt som "en af kilderne" og i landets første grundlov af 1923 hed det blot, at islam var statens officielle religion (Fegiery 2016).

Men Sadats muligheder for at opretholde billedet af sig selv som de troendes præsident og en oprigtig muslim blev gennem 1970'erne vanskeligere. Han sikrede sig ganske vist betydelig folkelig opbakning, da det i oktober 1973 lykkedes den egyptiske hær at krydse Suezkanalen og militært sætte sig fast flere steder på Sinai-halvøen, der var blevet erobret af Israel tilbage i 1967-krigen. Men den folkelige opbakning blev sat over styr, da præsidenten i 1977 efter tophemmelige forberedelser fløj til Israel og i en tale i det israelske parlament tilbød en fredsaftale. Den blev efterfølgende forhandlet på plads i Camp David under præsident Carters formelle ledelse og underskrevet på plænen ved Det Hvide Hus i Washington i marts 1979. Sadats initiativ blev stærkt kritiseret af et meget bredt udsnit af egyptere og udlagt som et knæfald for USA/Vesten og en kapitulation i forhold til Israel. Den øvrige arabiske verden reagerede også og organiserede en boykot af landet samt besluttede at flytte Den Arabiske Ligas hovedkontor til Tunis. De militante islamistiske grupperinger intensiverede deres kritik af regimet og en lille gruppe etableret i et samarbejde mellem Jama'at al-Jihâd og Jama 'at al-Islamiyya gennemførte i oktober 1981 et attentat på Sadat. Gruppens medlemmer havde forud for kuppet studeret en lille pamflet skrevet af Abd al-Salam Faraj (1954-1982) med titlen 
al-farîda al-ghâ'iba, den glemte forpligtelse, hvor forfatteren med tydelig inspiration fra Sayyid Qutb gjorde gældende, at Sadats regime var et eksempel på et muslimsk regime, der med overlæg forsøgte at skjule, at jihâd i virkeligheden var en af islams oprindelige religiøse pligter og derfor en pligt for alle muslimer (Jansen 1986). Men heller ikke i denne sammenhæng lykkedes det de militante islamister at formulere sig på en måde, der udløste folkelig støtte. Kritikken af Sadats politik var som nævnt bredt funderet, men at det skulle være en legitim begrundelse for et dødeligt attentat blev afvist. Den militante islamisme havde nok støtte hos enkelte, men fik aldrig held med at vinde udbredt folkelig støtte - heller ikke selv om de tog udgangspunkt i de samme populistiske begreber som både Broderskabet og skiftende nationalistiske grupperinger havde benyttet. Den brede ægyptiske befolkning kunne ganske enkelt ikke identificere sig med budskabet.

Shahstyrets fald - og islamistisk massemobilisering

Anderledes kom det til at gå i Iran, hvor Pahlavi-dynastiet i januar 1979 gik til grunde i et opgør med en alliance af indbyrdes meget forskellige ideologiske grupperinger. De enedes i oktober 1978 i Paris om et strategisk samarbejde, der i januar 1979 slutteligt tvang shahen i eksil (Bakhash 1986). Muhammad Reza (1919-1980) havde i begyndelsen af 1960'erne sat et reformprojekt betegnet som Den Hvide Revolution i gang med det erklærede mål at gøre Iran til regionens førende stat i et tæt samarbejde med Vesten (Reza Pahlavi, 1971). De bærende ideer i shahens reformer blev stærkt kritiseret af religiøse grupperinger i Qum, men kritikken og demonstrationerne fik ikke nævneværdig støtte fra befolkningen. Ayatollah Khomeini (1902-1989) måtte som konsekvens heraf se sig selv sendt i eksil, og efter et kort ophold i Tyrkiet fik han asyl i Irak, hvor han slog sig ned i Najaf, der historisk var et af de førende shiamuslimske lærdomscentre i landet. Her holdt han i 1970 en række forelæsninger, der efterfølgende blev udgivet i bogform med titlen Den Islamiske Regering (oversat i Algar 1981). I forelæsningerne argumenterede han for nødvendigheden af at skabe et politisk system funderet på islam, fordi kun et sådant kunne sikre den sociale retfærdighed, Koranen foreskriver. Han gjorde sig i forelæsningerne også til talsmand for en ændring i den måde, de religiøse lærde arbejdede på og opfordrede direkte de yngre muslimske lærde til at være langt mere direkte, når de henvendte sig til den brede befolkning. Deres budskaber og konkrete anvisninger skulle tilpasses den konkrete sociale, politiske og økonomiske situation, som karakteriserer det liv, befolkningen lever, og det råd må siges at være blevet taget eftertrykkeligt til efterretning af ganske mange religiøse lærde gennem de følgende årtier.

Khomeini selv evnede dette til fuldkommenhed, og hans mange forelæsninger og taler blev i Najaf optaget på kassettebånd og gennem 1970'erne smuglet ind i Iran for efterfølgende at blive delt ud til befolkningen $i$ alle egne af landet. Iranernes sympati for shah-regimet blev mindre og mindre og udviklede sig slutteligt til en regelret util- 
fredshed, udløst af voksende sociale spændinger for større og større dele af befolkningen, der slet ikke fik fordele af de stigende indtægter, Iran sikrede sig gennem 1970 'erne som følge af de voldsomme stigninger i prisen på olie. Khomeini selv og mange andre religiøse lærde evnede at drage fordel af den voksende sociale polarisering i det iranske samfund (Algar (1981) giver adskillige eksempler på sådanne taler). Shahstyret blev beskyldt for at arbejde tæt sammen med udlandet navnlig USA, og den iranske overklasse blev skildret som landsforrædere, der som shahen selv misbrugte deres positioner til at berige sig og dermed fratage den brede iranske befolkning mulighed for at nyde godt af landets rigdomme. Khomeini-gruppens budskab blev således italesat på bedste populistiske vis.

En amerikansk antropolog ved navn Michael Fischer, der i efteråret 1978 var på feltarbejde i Iran, fulgte på nærmeste hold udviklingen i det endelige opgør med shahen og kunne dokumentere, hvorledes demonstrationerne gennem shahstyrets sidste måneder omhyggeligt blev orkestreret med inspiration fra imam Hussains martyrium ved Kerbala tilbage i 681 (Fischer 1980). Gennem efteråret 1978 blev det historiske drama ved Kerbala italesat $i$ et populistisk narrativ, der tog udgangspunkt i den konkrete sociale og politiske situation, Iran befandt sig i. Den populistiske italesættelse, kredsen omkring Khomeini evnede at gøre brug af, var helt afgørende for den omfattende mobilisering, som oppositionen mod shahen satte i scene i det endelige opgør om magten i landet fra november 1978 til januar 1979.

Shahens endelige fald i januar 1979 udløste en voldsom intern borgerkrigslignende kamp mellem sekulære venstreorienterede grupper på den ene side og kredsen omkring Khomeini på den anden. Også i den sammenhæng lykkedes det Khomeinigruppen at beskrive situationen i termer og billeder hentet fra den shiamuslimske tradition. De sekulære politiske grupperinger blev skildret som lakajer for udenlandske interesser og ikke som sande og autentiske iranere. Kredsen bag Khomeini fik ved en folkeafstemning i marts 1979 bred folkelig opbakning til etablering af en islamisk republik, og den nye grundlov sikrede, at centrale elementer af Khomeinis skrift om den islamiske regering blev lagt til grund for det nye politiske system, der efterfølgende blev etableret (Schirazi 1998). Og da Irak i september 1980 invaderede Iran og kortvarigt sikrede sig kontrol over Khuzistan-provinsen, lykkedes det endnu en gang det nye regime at italesætte situationen med brug af den shiitiske tradition. Borgerkrigen blev bragt til afslutning i løbet af sommeren 1982, hvor det lykkedes kredsen omkring Khomeini definitivt at nedkæmpe oppositionen og tvinge den i eksil (Arjomand 1988). Krigen mod Irak varede frem til en våbenhvile blev indgået i oktober 1988, men gennem hele krigen evnede det nye regime at fortolke krigen som et angreb på det sande iranske shiamuslimske folk (Johnson 2011).

Den populistiske ideologisering af islam var tidligere blevet sat på ord af den iranske sociolog Ali Shariati (1933-1977) og hans syntese mellem shia-islam og socialisme fik ganske bred tilslutning fra intellektuelle kredse, og det var denne tendens, der blev afgørende for, at det i januar 1979 lykkedes oppositionen at bringe shah-styret til fald, og dermed var islamismens potentiale for populistisk mobilisering til fulde doku- 
menteret. Det skulle gennem 1980'erne gentage sig med etableringen først af Hizballah i Libanon og siden Hamas i Gaza (Alagha 2011; Gunning 2007). Begge grupper formulerede deres synspunkter med brug af en stærk anti-imperialistisk retorik, der også havde karakteriseret mobiliseringen i Iran. Tendensen fik yderligere fremdrift, da det i 1988 lykkedes en alliance mellem de afghanske talibanere og frivillige mujâhidûn fra forskellige lande rundt om i den muslimske verden at tvinge USSR ud af Afghanistan (Hamid og Farrall 2015). I løbet af et årti havde populistisk islamisme bidraget til at bringe to regimer til fald, der havde støtte fra de to eksisterende supermagter USA (der støttede shahstyret i Iran) og USSR (der støttede det kommunistiske styre i Afghanistan). Og dermed var fundamentet for den forskydning, som den militante islamisme oplevede fra begyndelsen af 1990'erne og frem, lagt. Militant islamisme blev transformeret fra at være et fænomen i den muslimske verden til at blive, hvad det har været siden: et internationalt sikkerhedsproblem. Militante islamister alene eller organiseret i mindre grupperinger har siden 2001 gennemført en stribe terrorangreb mod den vestlige verden. Angrebene og de islamistiske grupperinger udgør ikke en reel fare for den vestlige verden, dertil er de for få og for uorganiseret, men de kan ramme hvor som helst, når som helst og påføre uskyldige civile lidelser og smerte (Turner 2014). At også den internationalt funderede militante islamisme forsøger at udtrykke sig i populistiske termer og begreber er tydeligt, men lige så tydeligt er det, at deres populistiske italesættelser ikke har evnet at mobilisere folkelig opbakning. Det gjaldt Usama bin Ladins opfordring til jihad mod jøder og korsfarere fra 1998 (Ibrahim 2007), og det gjaldt Abu Muhammad al-Adnani, der 29. juni 2014 udråbte kalifatet (Lister 2015). Ingen af disse initiativer fik bred folkelig opbakning som tilfældet var det med Det Muslimske Broderskab i Egypten og kredsen omkring Khomeini i Iran.

\section{Post-islamisme}

Gennem hele det 20. århundrede har islamisme været en del af det politiske og kulturelle liv i Mellemøsten, og fra 1970'erne og frem slog islamisme også igennem i den tyrkiske republik, der var blevet etableret i 1923 på et klart formuleret sekulært grundlag (White 2002). Periodisk har den islamistiske bevægelse været under voldsomt pres, men hver gang er den dukket op igen og interessant nok ofte i nye former og med nye udtryk. Det blev synligt i Egypten gennem 1990'erne, hvor en ny individuel variant af islamisme slog igennem. Det blev erkendt af flere og flere militante grupperinger, at den stat, de gerne ville sikre sig kontrol over, var stærkere end som så og derfor ikke lod sig nedkæmpe. Når det lykkedes kredsen omkring Khomeini at etablere en islamisk republik i Iran var det derfor et udtryk for et sammenfald af særlige politiske og økonomiske omstændigheder. Resultatet blev, at flere militante grupperinger i Egypten opgav kampen og erklærede sig rede til forhandling med systemet, hvis deres fængslede medlemmer blev løsladt efter den model, som Sadat i midten af 1970'erne indgik med Det Muslimske Broderskab. 
Dermed var den militante islamismes drøm om at sikre sig kontrollen med staten opgivet, men islamismen som fænomen var ikke gået i graven. Allerede i 1980'erne havde medlemmer af Broderskabet og andre med samme tilgang taget initiativ til at engagere sig i de eksisterende faglige og professionelle organisationer, og dermed påviste de, at der var mulighed for at præge udviklingen i landet uden om det traditionelle politiske system. Tendensen kunne også aflæses $i$ et voksende individuelt engagement $i$ et sandt flor af tilbud drevet af islamistiske aktivister af den type, der havde karakteriseret Broderskabet, men nu ofte sat i gang af personer, der nok var islamister men ikke nødvendigvis medlemmer (Ismail 2004; Saba 2005; Ismail 2006). Tendensen blev forstærket af den nye medievirkelighed, der slog igennem i den mellemøstlige verden fra midten af 1990 'erne og frem. Private fik med ny teknologi adgang til TV (Galal 2009; Gräf og Skovgaard-Petersen 2009) og eksempelvis prædikanten Khaled Amr fik stor betydning for mange egyptere, fordi han fastholdt, at man som troende muslim udmærket kunne engagere sig i det private erhvervsliv. Et udbytterigt engagement var ikke i modstrid med den fortolkning af islam prædikanten formulerede i sine TV-udsendelser (Sætren 2006; Olsson 2013). Islam blev på den måde fra midten af 1990'erne og frem for mange et individuelt engagement, og en måde hvorpå den enkelte i praksis kunne synligøre islams relevans for det moderne liv ved udgangen af det 20. århundrede, og tendensen er blevet fortsat i begyndelsen af det 21. århundrede (Brown 2016).

Denne form for islamisme er af flere forskere betegnet som post-islamistisk. Islamisme er i denne forståelse ikke længere et politisk engagement om magt, og islam er ikke formuleret som en politisk ideologi, således som den blev det af en lang række radikale og militante islamistiske grupperinger i de foregående årtier. Islamisme blev nu transformeret til et individuelt engagement, der helt i overensstemmelse med moderniteten kan forbinde den enkelte troende til et utal af forskellige grupperinger af aktive medborgere med henblik på at støtte personer, som i en given sammenhæng har brug for hjælp og støtte af forskellig art: Gratis juridisk rådgivning i forhold til kommunale og/eller statslige institutioner; rådgivning i forbindelse med graviditet; støtte til lektielæsning; støtte til ældre med nedsat fysisk bevægelighed eller støtte til kvinder, der har været udsat for vold og/eller seksuelle overgreb (Bayat 2007; Bayat 2009). Når sådanne initiativer skal begrundes sker det igen med brug af populistiske referencer: Det skal modvirke den vestlige verdens indflydelse, og det skal genskabe sande værdier og sikre en udvikling, der tager rod i de traditioner og med de værdier, der nu lokalt gør sig gældende. Dermed har den populisme, som denne type islamisme præsenterer fundet nye veje at italesætte og håndhæve et aktivistisk engagement - og så længe islamisme evner at italesætte sig selv på den måde vil den forblive en dynamisk størrelse i Mellemøsten (Bayat 2007; Bayat 2009). 


\section{Konklusion}

Det Muslimske Broderskab diskuterede helt tilbage i 1990'erne om tiden var inde til at bevægelsen etablerede sig som et regelret politisk parti. En række medlemmer var i 1996 med til at danne partiet Wasat - et ord der betegner 'midte' - men bevægelsens ledelse afviste initiativet. Først da Mubarak blev tvunget til at trække sig tilbage i februar 2011 og dermed satte en udvikling i gang mod skabelsen af et nyt politisk system i Egypten, besluttede Broderskabet at danne Retfoerdighedspartiet. Ved valget til parlamentet i 2012 blev partiet det største parti, medens det salafistiske al-Nur-parti blev det næststørste parti i det nyvalgte parlament (Boserup 2016). Ved præsidentvalget samme år blev Muhammad Mursi (født 1951), der gennem mange år havde været medlem af Broderskabet, valgt til ny præsident ved det første frie præsidentvalg i Egyptens moderne historie. Men året efter måtte han se sig fjernet fra magten af sin forsvarsminister Abd al-Fatah al-Sisi (født 1954), der siden har siddet tungt på magten (Hokayem 2016). Det nye militære regime har igen forbudt Broderskabet, fængslet et meget stort antal medlemmer af bevægelsen og i skueprocesser dømt mange til døden eller til lange fængselsstraffe. At dømme efter den opbakning, Broderskabet fik ved valgene i 2012 taler intet for, at det vil lykkes al-Sisis regime at knække endsige tilintetgøre Broderskabet, men naturligvis nok at gøre betingelserne for dets fortsatte virke vanskeligt. Imens må individuelle personer opretholde den tolkning af islam som tilsyneladende fortsat har udbredt støtte i den brede befolkning. Et af midlerne hertil er en populistisk strategi med løbende tilkendegivelser af, hvorledes det sande muslimske Egypten skal forholde sig. Det har siden begyndelsen af etableringen af Broderskabet i 1928 kunnet dokumenteres, at islamisme er populistisk men også at den mellemøstlige populisme er blevet islamistisk som tilfældet med etableringen af Den Islamiske Republik Iran i 1979 har vist.

\section{Litteratur}

Alagha, J. (2011). Hizbullah's Identity Construction. Amsterdam: Amsterdam University Press.

Algar, H. (1981). Islam and Revolution: Writings and Declarations of Imam Khomeini, oversat and kommenteret af H. Algar. Berkeley: Mizan Press.

Angrist, M.P. (2013). Politics \& Soceity in the Contemporary Middle East, 2. udg. Boulder \& London: Lynne Rienner Publishers.

Arjoumand, S.A. (1988). The Turban for the Crown: The Islamic Revolution in Iran. Oxford \& New York: Oxford University Press.

Ayoob, M. (2009). Religion and Politics in Saudi Arabia: Wahhabism and the State. Boulder: Lynne Rienner Publishers.

Bakhash, S. (1986). The Reign of the Ayatollahs. London: Unwin Paperbacks. 
Banna, S.al-. (1975). Five Tracts of Hassan al-Banna, oversat af C. Wendell. San Francisco: University of California Press.

Bayat, A. (2007). Making Islam Democratic: Social Movements and the Post-Islam Turn. Stanford: Stanford University Press.

Bayat, A. (2009). Life as Politics: How Ordinary People Changed the Middle East. Stanford: Stanford University Press.

Bergesen, A.J. (2008). The Sayyid Qutb Reader. New York \& London: Routledge.

Boserup, R.A. (2016). Efter foråret: forandringer $i$ arabisk politik. København: Gyldendal.

Brown, N.J. (2017). Arguing Islam after the Revival of Arab Politics. New York: Oxford University Press.

Cook, S.A. (2012). The Struggle for Egypt: From Nasser to Tahrir Square. New York \& London: Oxford University Press.

Fegiery, M.El-. (2016). Islamic Law and Human Rights: The Muslim Brotherhood in Egypt. Cambridge: Cambridge Scholars Publishing.

Finklestone, J. (1998). Anwar Sadat: Visionary who Dared. London: Frank Cass.

Fischer, M.M.J. (1980). Iran: From Religious Dispute to Revolution. Cambridge, Mass.: Harvard University Press.

Freeden, M., Sargent, L.M. og Stears, M. (red.) (2013). The Oxford Handbook of Political Ideologies. Oxford: Oxford University Press.

Galal, E. (2009). Identiteter og livsstil på islamisk satellit-tv. En indholdsanalyse af udvalgte programmers positionering af muslimer. København, ph.d.-afhandling, Det Humanistiske Fakultet, Københavns Universitet.

Gräf, B. og Skovgaard-Peteren, J. (2009). The Global Mufti. The Phenomenon of Yusuf al-Qaradawi. New York: Columbia University Press.

Gunning, J. (2007). Hamas in Politics: Democracy, Religion, Violence. London: Hurst \& Company.

Hamid, M. og Farrall, L. (2015). The Arabs at War in Afghanistan. London: Hurst.

Hirst, D. \& Beeson, I. (1981). Sadat. London: Faber and Faber.

Hokayem, E. (2016). Egypt after the Spring: Revolt and Reaction. Washington: The International Institute for Strategic Studies.

Ibrahim, R. (2007). The al-Qaeda Reader. New York: Broadway Books.

Ismail, S. (2003). Rethinking Islamist Politics, Culture, the State and Islamism. London: I.B. Tauris.

Ismail, S. (2006). Political Life in Cairo's New Quarters: Encountering the Everyday State. Minneapolis: University of Minnesota Press.

Janice, J.T. (1982). The Wafd 1919-1952. Cornerstone of Egyptian political Power. London: Third World Centre for Research and Publication.

Jansen, J.J.G. (1986). The Neglected Duty: The Creed of Sadat's Assasins and Islamic Resurgence in the Middle East. New York: Macmillan Publishing Company.

Johnson, R. (2011). The Iran-Iraq War. Basingstoke: Palgrave Macmillan. 
Kepel, G. (2003). Muslim Extremism in Egypt: Prophet and Pharaoh. Berkeley: University of California Press.

Lia, B. (1998). Society of the Muslim Brothers in Egypt: The Rise of a Mass Movement. Reading: Ithaca Press.

Lister, C.R. (2015). The Syrian Jihad. Al-Qaeda, the Islamic State and the Evolution of an Insurgency. Oxford: Oxford University Press.

Mahmoud, S. (2012). Politics of Piety: The Islamic Revival and the feminine Subject. Princeton, N.J.: Princeton University Press.

Mitchell, R. (1969). The Society of the Muslim Brothers. New York: Oxford University Press.

Mudde, C. og Kaltwasser, C. (2013). Populism. I: M. Freeden, L.T. Sargent og M. Stears (red.). The Oxford Handbook of Political Ideologies. Oxford: Oxford University Press.

Müller, J.-W. (2016). Hvad er populisme? København: Informations Forlag.

Nasir, G.A. al-. (1954). The Philosophy of the Revolution. Cairo: Ministry of Information.

Olsson, S. og Kersten, C. (2013). Alternative Islamic Discourses and Religious Authority. Farnham: Ashgate Publishing Ltd.

Reza Pahlavi, M. (1971). Den Hvide Revolution. København: Nyt Nordisk Forlag Arnold Busck.

Rogan, E. (2009). The Arabs: A History. London: Allen Lane.

Rutherford, B. (2013). Egypt under Mubarak: Liberalism, Islam and Democracy in the Arab World. Princeton: Princeton University Press.

Schirazi, A. (1998). The Constitution of Iran: Politics and the State in the Islamic Republic. London: I.B. Tauris.

Sætren, J.E. (2006). Islamisk diskurs I nye medier: predikanten Amr Khalid. Bergen: University of Bergen.

Toth, J. (2013). Sayyid Qutb: The Life and Legacy of a Radical Islamic Intellectual. New York. Oxford University Press.

Turner, J.A. (2014). Religious Ideology and the Roots of Global Jihad, Salafi Jihadism and International Order. Basingstoke: Palgrave Macmillan.

Vatikiotis, P.J. (1980). The History of Egypt. From Muhammad Ali to Sadat. London: Weidenfeld and Nicolson.

Waterbury, J. (1983). The Egypt of Nasser and Sadat: The Political Economy of two Regimes. Princeton: Princeton University Press. 